\title{
Effect of height and colour of bee bricks on nesting occupancy of bees and wasps in SW England
}

\author{
Rosalind F. Shaw ${ }^{1 *}$, Kate Christman ${ }^{2,3}$, Rachel Crookes ${ }^{1}$, Chris N. Gilbert ${ }^{1}$, Juliet L. Osborne ${ }^{1}$ \\ https://doi.org/10.52201/CEJ18KMBE7709 \\ ${ }^{1}$ Environment and Sustainability Institute, University of Exeter, Penryn Campus, TR10 9FE \\ ${ }^{2}$ Falmouth University, Woodlane, Falmouth, TR11 4RH \\ ${ }^{3}$ Green\&Blue, New Road, Perranporth, TR6 ODL
}

\section{SUMMARY}

Bee bricks are a novel solitary-bee nesting habitat made from reclaimed concrete, designed to be built into walls to provide nest sites in urban areas. We tested if cavity-nesting bees and wasps used bee bricks, and if they showed any preference for nesting in bricks of different colours or at different heights. We carried out surveys of solitary bees in 15 private urban gardens and eight rural public gardens, where the bee bricks were then placed for two years (2016-2017). Bee bricks were placed on structures that were either $1 \mathrm{~m}$ in height with 4 bricks (red, yellow, white and wooden control) or with three platforms where white bricks were placed at $0 \mathrm{~m}$, $0.6 \mathrm{~m}$ or $1.0 \mathrm{~m}$ above the ground. The number of occupied nest holes was counted at the end of each summer. Nesting holes that were capped with mud were more common than those capped with chewed or cut leaves. The average \% of holes capped with either mud or chewed leaf was greatest in red bricks and lowest in wooden controls. Only one brick out of 39 placed at ground level had capped holes, although the difference in the \% of holes capped between heights was not statistically significant. Cavity-nesting bees and wasps use solitary-bee bricks for nests, but population level impacts are still untested.

\section{BACKGROUND}

There is growing concern over the decline of pollinator species worldwide due to habitat loss, agrochemical use, and disease (IPBES 2016). Urban areas have been identified by some studies to support larger, more diverse, pollinator populations than in agricultural areas (Baldock et al. 2015). Urban areas may support more pollinators due to their increased floral resources in terms of both floral diversity and length of flowering season. This means that many management actions and studies focus on floral resources. The relative need for floral vs nesting resources is unknown, but the number of nest sites may be limiting for some pollinators in some habitats (e.g. Threlfall et al. 2015).

Artificial bee nesting structures are a management option suggested to help declining solitary bee populations. Unlike bumblebee nest boxes, which have been relatively unsuccessful (Lye et al. 2011), a large number of studies (including 45 listed on Conservation Evidence under the action 'Provide artificial nest sites for solitary bees' and 30 assessed by Dicks et al. (2010) in the Conservation Evidence synopsis) have shown that solitary bees will readily nest in artificial nesting structures (like 'bee hotels') and their offspring will successfully emerge the following year (Dicks et al. 2010, MacIvor 2017). In addition to solitary bees, a range of solitary wasps, including members of the Crabronidae, Pompilidae, Psenidae, Sphecidae and Vespidae families (Königslöw et al. 2019) and some UK Red Databook species such as Ancistrocerus antilope (Bees Wasps $\&$ Ants Recording Society 2001), will use trap nests.

*corresponding author email address r.shaw@exeter.ac.uk
Solitary wasps provision cells with prey such as other invertebrates. In addition to cavity-nesting solitary bees and wasps, there are many associated species of Diptera, Hymenoptera and Coleoptera that parasitise the nests.

There is a large amount of variation in occupation rates across studies using artificial nests, the most successful of these typically being made either of wood with drilled holes or bamboo canes bundled together (MacIvor 2017); these are thought to most accurately mimic the bees and wasps' natural nesting places. One way to improve bee and wasp nesting habitat within urban areas is to include habitat within built structures, such as houses and walls; a novel product, the solitary-bee brick (https://www.greenandblue.co.uk/products/beebrick), has been developed to do this. The bricks are the same dimensions as a standard house brick (215 $\mathrm{mm} \times 105 \mathrm{~mm}$ x $65 \mathrm{~mm}$ ) and include 19 holes varying in diameter from 5-8 mm, and with a depth of 70-80 $\mathrm{mm}$. However, we do not know whether bees and wasps actually nest in them and if so, which species use the bricks and whether uptake rates are similar between bricks and other artificial nest habitats. The bricks are designed to be built into walls, and to colour match commonly used bricks (yellow, red and white). The recommendations are to place bricks at 1 $\mathrm{m}$ off the ground. The bricks are also sold as individual units so people may place them in their garden at whatever height they have available.

In this study we investigated bee and wasp nesting rates in bee bricks of different colours (red, white, yellow) and at different heights above the ground $(0.0$ 
$\mathrm{m}, 0.6 \mathrm{~m}, 1.0 \mathrm{~m}$ ) and compared to a wooden nesting structure, the same size and dimension as the bee brick with the same pattern of holes drilled into it. Drilled wood blocks have been shown to be used by both bees (Dicks et al. 2010) and wasps (Königslöw et al. 2019). Bricks were placed in both private urban gardens and public rural gardens to ensure that a range of Hymenopteran species were present, and at sites with a range of natural floral and nesting resources.

\section{ACTION}

This study was carried out in Cornwall, southwest UK (SW corner $50.142586^{\circ} \mathrm{N},-5.1295853^{\circ} \mathrm{E}$, NE corner $50.259059^{\circ} \mathrm{N},-5.0039291^{\circ} \mathrm{E}$ ). The trial of bricks was carried out in private gardens but also large public gardens, to assess their occupancy in a range of habitats. Urban gardens were defined as domestic gardens within a town, whereas public gardens consisted of large gardens that were open to the public and situated within a rural landscape. Fifteen urban gardens and eight public gardens were used. The public gardens were sufficiently large that both the height and colour experiment could be carried out within the same garden, whereas domestic gardens were generally smaller and could only support one kind of test. All test sites were separated by a minimum of $600 \mathrm{~m}$, which is the maximum foraging distance of solitary bees recorded by Gathmann \& Tscharntke (2002). Due to the difficulty of establishing bricks in a wall, the bricks were set up on wooden structures and then placed against a wall (19/24 sites) or fence where available to mimic their use in urban areas. Walls were a variety of colours and construction including red brick, pebble-dashed, coloured render and granite. Structures were placed so that the bricks faced south or south-east/west. To test the impact of height, three white bricks were placed on wooden shelves attached to a wooden post at $0 \mathrm{~m}, 0.6 \mathrm{~m}$ and $1.0 \mathrm{~m}$ above the ground (Fig 1a). The control wooden brick was placed on top of one of the bricks with the height location varied randomly at each site (resulting in 3-6 control bricks at each height). For the colour test, four bricks (white, red, yellow, control) were placed on a wooden shelf at 1.0 $\mathrm{m}$ above the ground (Fig 1b). The order of the colour and the control from left to right was varied randomly between sites. The bricks were set up between 30 April 2016 and 2 May 2016 and surveyed between 28 June 2016 and 3 July 2016. The bricks were left out over winter before being re-surveyed between 22 August 2017 and 1 September 2017. Three urban sites could not be re-surveyed in 2017 due to lack of access. The number of available holes was counted as was the number capped using mud (by species such as red mason-bees Osmia bicornis), chewed-leaf material (such as by mason bees Osmia spp) and cutleaf material (such as Willughby's leafcutter bee Megachile willughbiella but also other Megachile spp, Falk and Lewington 2015). There are also a number of cavity-nesting wasps that may potentially use the bricks including species that use mud (such as Trypoxylon figulus, Euodynerus spp, Microdynerus spp.), or plant material (such as Passaloecus spp) (Osorio-Canada et al. 2018).

\section{Bee surveys}

To confirm the presence of solitary bees at each site, a $1 \mathrm{~km}$ transect count of solitary bees foraging or flying was carried out twice at each of the sites during May and June 2016. The habitat varied around each transect but was typical of that in the surrounding area; for example, along paths and pavements in urban areas or through ornamental gardens and surrounding rural habitats in public garden sites. Each transect had the experimental nesting sites at the centre, extending approximately east and west of the site and were mapped in advance, following roads and pathways. Bees observed within $1 \mathrm{~m}$ either side and $2 \mathrm{~m}$ above the transect were either identified on the wing or caught and identified to species following Falk \& Lewington (2015). The transects were carried out between $10.00 \mathrm{~h}-16.00 \mathrm{~h}$ on days with temperatures above $15^{\circ} \mathrm{C}$ and wind speed below Beaufort scale force 4 .

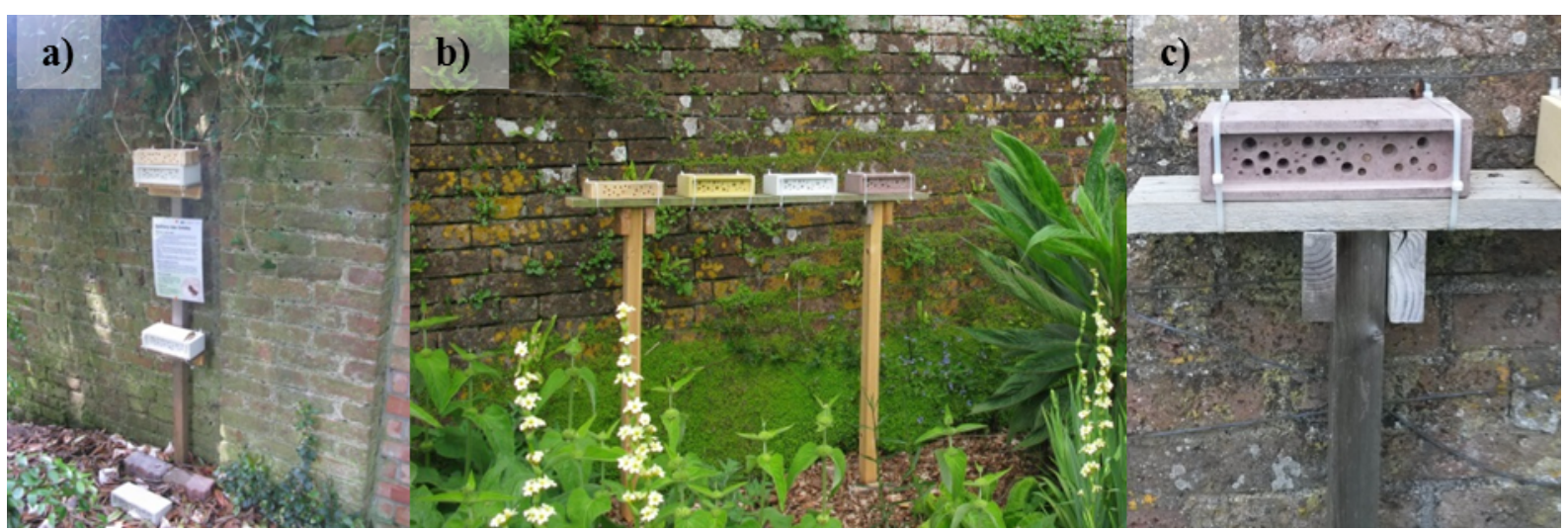

Figure 1 a) Testing the height of the bricks. Note that in this picture the wooden control is at top height, but this was varied between sites; b) bricks of three different colours: white, red and yellow and wooden control, at one site; and c) red brick with occupied cells. 


\section{Analysis}

All analysis was carried out using $\mathrm{R}$ ( $\mathrm{R}$ Core Team, 2016). The number of species and the abundance of solitary bees seen on the transects in urban vs public gardens was summed across both sample dates before being analysed using a general linear mixed effects model with a Poisson distribution (package lme4 Bates et al. 2015). As there were two transects at the eight public garden sites, site was entered as a random effect for these models, with garden type (urban or public) as the explanatory variable. There was no significant difference between public and urban gardens, so they were not treated separately in further analysis. Model assumptions were checked using a simulation approach for Poisson (package DHARMa Hartig 2018). Poisson models were checked for overdispersion.

Percent occupancy of bricks was compared using Friedman's test, a non-parametric test that can be used to compare more than two groups of data that are matched in some way (Friedman, 1937). The Wilcoxon-Nemenyi-McDonald-Thompson test, which accounts for multiple tests, was used as a post hoc test of differences between groups for those with an overall significant result (Hollander et al. 1999). Site was used as the block structure for all tests. For the colour experiment, colour was the group with four levels (red, white, yellow, wooden control). For the height experiment, using bricks only, the group was height with three levels: bottom $(0 \mathrm{~m})$, middle
$(0.6 \mathrm{~m})$, top $(1.0 \mathrm{~m})$. The wooden controls in the height experiment were compared with the bricks at the same height only. The different capping materials were analysed separately, as different groups of bee species may have different preferences for nesting sites. However, this meant that for chewed-leaf-capped or cut-leaf-capped holes there were not always sufficient data to formally test.

\section{CONSEQUENCES}

\section{Presence of solitary bees on transects}

There was a slightly higher number of solitary bees observed foraging and flying in urban gardens vs large public gardens (Table 1, Fig. 2) but neither the number of species nor the abundance was significantly different between garden types (back transformed mean no. species \pm standard error: public gardens $2.9 \pm 0.47$, urban gardens $4.1 \pm 0.54$, $\mathrm{z}=-1.67, \mathrm{p}=0.0957$; mean abundance public gardens $5.5 \pm 1.34$, urban gardens $8.2 \pm 1.22, \mathrm{z}=$ $1.457, \mathrm{p}=0.145)$. The majority of solitary bees observed (186/213 individuals) were those that dig nest burrows in soil (mining bees) rather than those that nest in plant stems or cavities (27/213 individuals, Table 1). However, at $7 / 15$ urban and at $7 / 8$ public garden sites cavity-nesting bees were seen on transects.

Table 1 The number of solitary bees (Hymenoptera from families Andrenidae, Halictidae and Colletidae but excluding social Hymenoptera such as bumblebees Bombus and honeybees Apis) observed on $1 \mathrm{~km}$ transects surveyed twice at each site. Information on nesting preference from Falk and Lewington (2015) and Danks (1971). Ground-nesting bees are summed per genus if more than one species. Cavity nesting includes those species that nest in masonry cavities, wood cavities and stems of plants. Cap type is the material nest caps are made from.

\begin{tabular}{llllll}
\hline Species or genus & $\begin{array}{l}\text { No. } \\
\text { species }\end{array}$ & $\begin{array}{l}\text { Cavity } \\
\text { nesting? }\end{array}$ & Cap type & $\begin{array}{l}\text { Public } \\
\text { gardens }\end{array}$ & $\begin{array}{l}\text { Urban } \\
\text { gardens }\end{array}$ \\
\hline Andrena spp. & 14 & No & & 30 & 85 \\
Colletes similis & 1 & No & & 3 & 2 \\
Halictus rubicundus & 1 & No & & 2 & 0 \\
Lasioglossum spp & 6 & No & Membrane & 33 & 31 \\
Hylaeus brevicornis & 1 & Yes & Membrane & 0 & 0 \\
Hylaeus communis & 1 & Yes & Membrane & 1 & 1 \\
Hylaeus hyalinatus & 1 & Yes & Cut-leaf & 2 & 2 \\
Megachile centuncularis & 1 & Yes & Cut-leaf & 1 & 0 \\
Megachile versicolor & 1 & Yes & Cut-leaf & 3 & 1 \\
Megachile willughbiella & 1 & Yes & Mud & 2 & 7 \\
Osmia bicornis & 1 & Yes & Chewed-leaf & 2 & 0 \\
Osmia leaiana & 1 & Yes & & 82 & 131 \\
\hline TOTAL & & & &
\end{tabular}



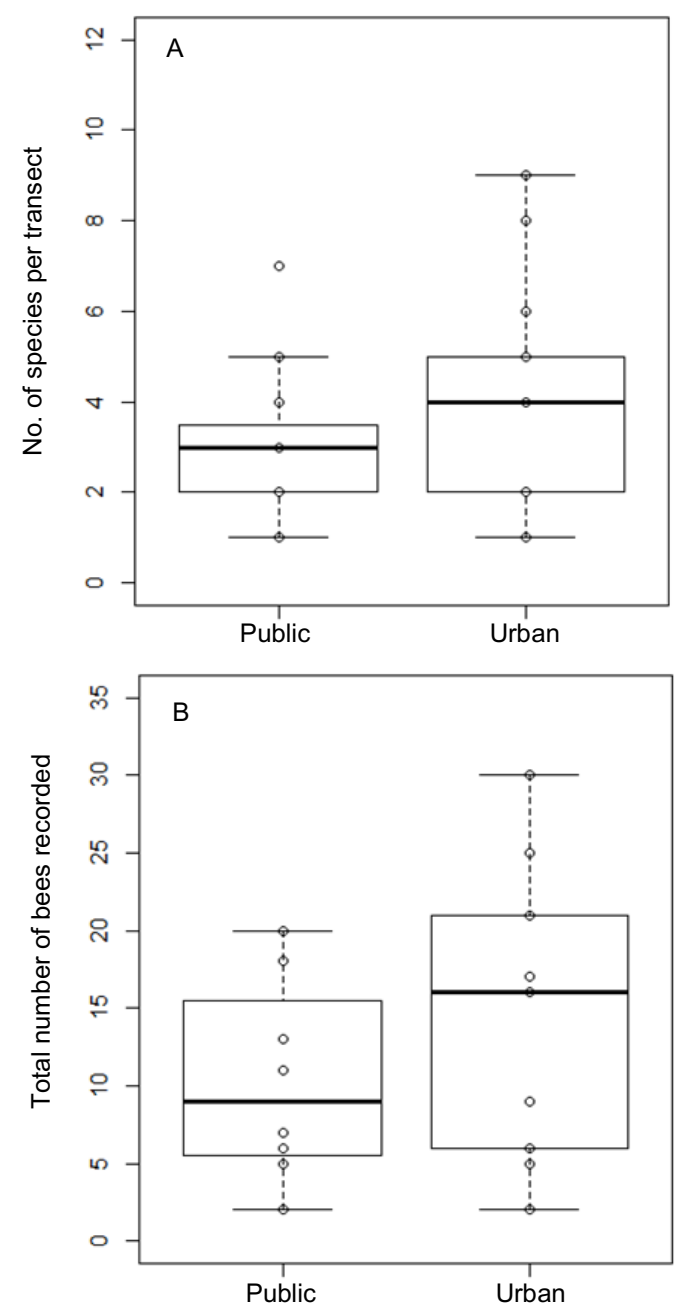

Figure 2 The number of solitary bee species seen (A) and total number of solitary bees (B) recorded in public or urban gardens in transects carried out in 2016. The central line is the median and the outer edges are the interquartile range. Points are values from each transect.

\section{Bee brick occupancy}

In 2016,66 brick holes were capped $(1.3 \%$ of 5,238 available holes) along with 19 wooden control holes (1.1\% of 1,722 available holes). In 2017, 125 brick holes were capped $(2.8 \%$ of 4,386 available holes) and 10 wooden control holes $(0.7 \%$ of 1,500 available holes). In 2016, 39 holes in rural public gardens were capped (1.1\% of 3,477 total holes) and 46 holes were capped in urban gardens $(1.3 \%$ of 3,483 holes) and in 2017 the values were 83 capped in rural public gardens ( $2.5 \%$ of 3,363 holes $)$ and 52 capped in urban gardens (2.1\% of 2,523 holes). Holes capped with three materials were observed mud, cut leaves, and chewed leaves. All capping types were observed at least once in bricks and wooden controls. Overall, 79\% of the capped holes across both years were capped with mud, 13\% were capped with cut leaves and $8 \%$ were capped with chewed leaves (total number of capped holes $=220$ ). No chewed leaf caps were observed in the height experiment in 2016 or 2017, or in the colour experiment in 2016. In general, occupancy was low with medians of 0 for all brick types (Fig. 3 ).

There was no significant difference between the $\%$ of holes occupied in wooden controls vs. bricks in either year, or for any type of capping material in the height experiment. There was no significant difference $(p=0.06)$ in the occupancy at different heights for mud-capping insects in 2017, however, capped holes were only observed in one groundlevel brick (Fig. 3). In the colour experiment there was an overall significant difference between the different colour bricks and controls for insects using cut leaves to cap nests in 2016; however, there were no statistically significant differences in the post hoc tests. For mud-capping species in 2017 the order of occupancy levels from highest to lowest was red $>$ yellow $>$ white $>$ control, but the only significant difference was between yellow bricks and controls $(p=0.047)$. In 2017 the number of nests capped with chewed leaves was greatest in red, then yellow, then white, then control, but the only significant differences were between red bricks and controls ( $p$ $=0.017)$ and between red and white bricks ( $p=$ $0.041)$.

\section{DISCUSSION}

The transects showed that there was a population of cavity-nesting bees in both the urban and more rural garden sites giving the opportunity for those bees to find the experimental nesting structures. Several species of cavity-nesting insects were shown to use bee bricks to build nests, and the occupancy levels in bee bricks were either not significantly different to, or higher than, in wooden controls. The percentage occupancy was highly variable between sites suggesting that at some sites, cavity-nesting Hymenoptera populations may be low, or that they may have alternative nesting habitats that they prefer. Species that cap their holes with mud were the most common bees or wasps using the bee bricks, with those using cut or chewed leaves much rarer. The numbers of all solitary bees in transect surveys were very low so it is unclear if this is due to nesting preference or differences in population sizes. There was a tendency for bricks at least $0.6 \mathrm{~m}$ off the ground to have a higher percentage of mudcapped holes, but this was not statistically significant. Further research in areas with large populations of cavity-nesting bees and wasps is needed to confirm any height preference. In terms of colour, there was a tendency in both mud-capping species and chewed-leaf-capping species to prefer red or yellow bricks. Both the height of the brick and the colour are likely to affect the temperature of the cavities, which is likely to have a strong impact on cavity choice (Wilson et al. 2020). Secondly, colour vision in leaf-cutting bees and mason bees is based on photoreceptors sensitive to UV, green and blue wavelengths (Peitsch et al. 1992). 
A) 2016

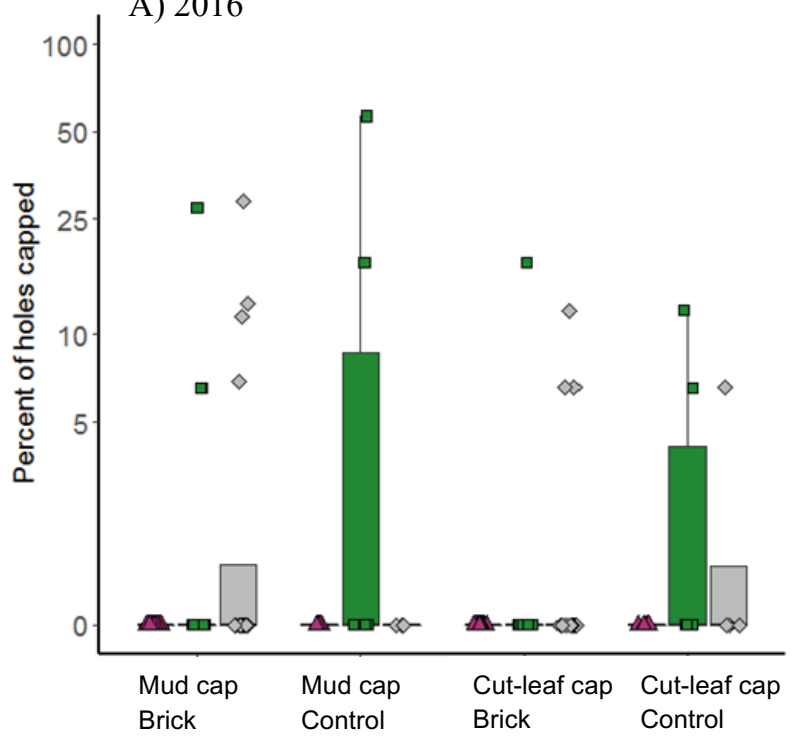

C) 2016

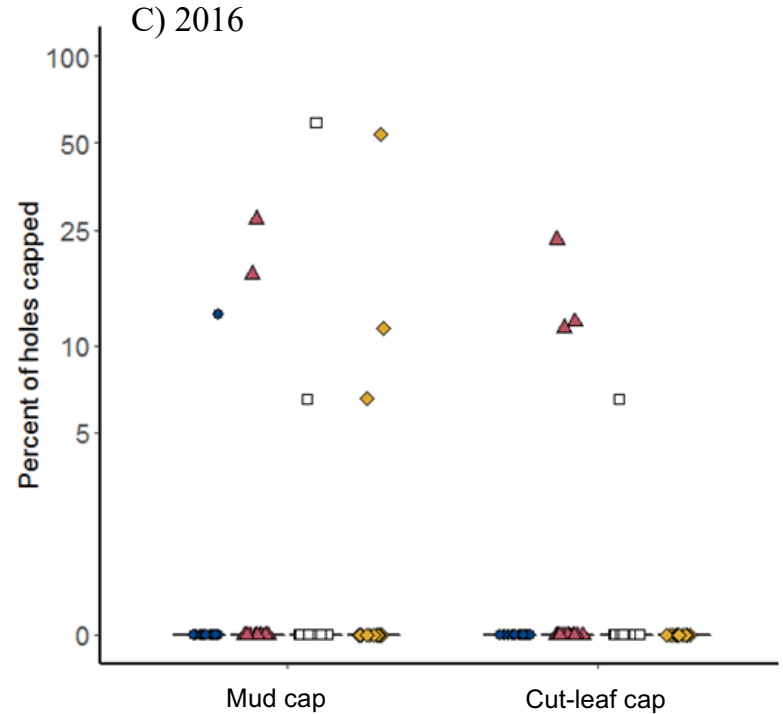

B) 2017

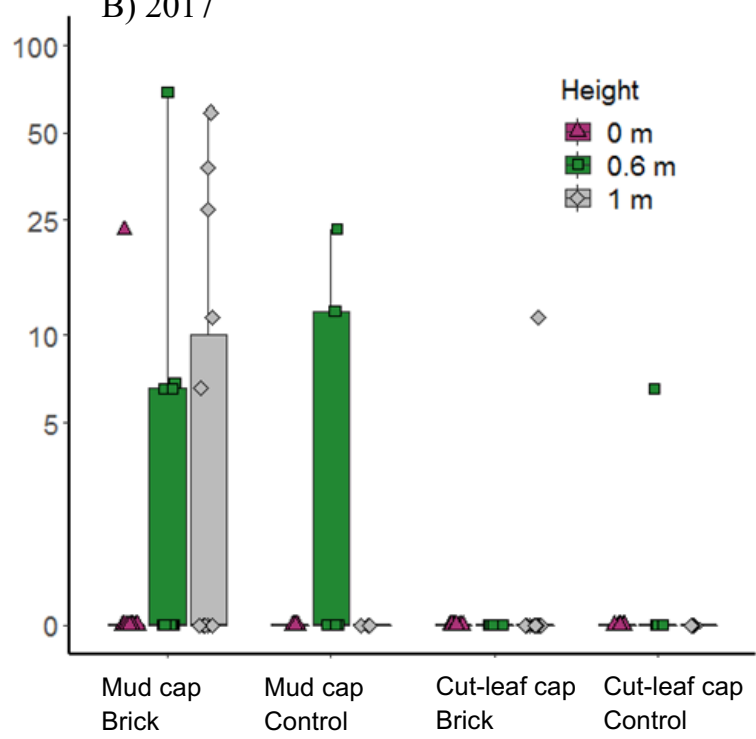

D) 2017

Colour

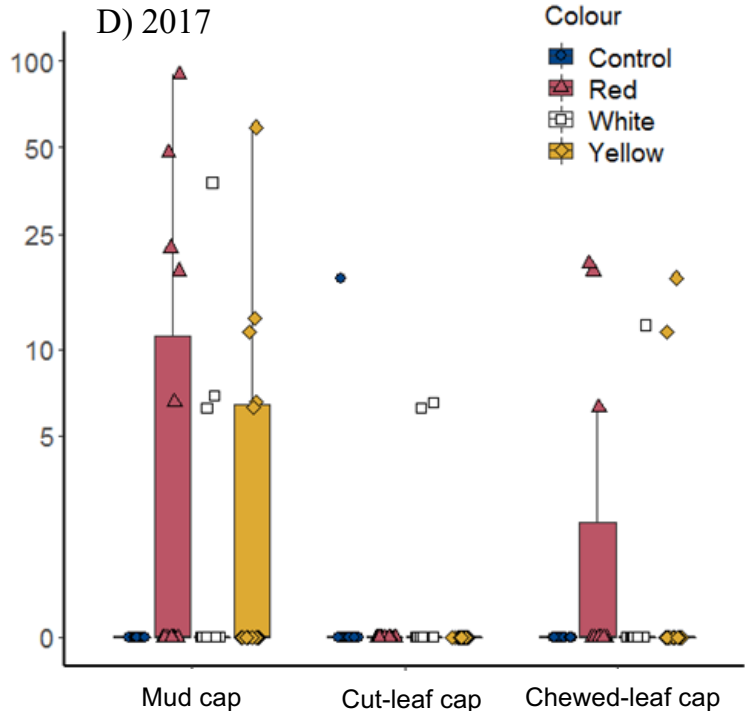

Figure 3 Box plots overlaid with points of the \% holes capped by different types of material (mud, cut leaves and chewed leaves) over two years of study $(2016,2017)$. Boxplots show median, interquartile range and outliers. Plots A) and B) give the \% holes capped, with mud or cut leaves, in white bricks (brick) and wooden controls (control) at three different heights above ground: $0 \mathrm{~m}, 0.6 \mathrm{~m}$ and $1.0 \mathrm{~m}$. Plots $\mathrm{C}$ ) and D) show the \% holes with mud, cut-leaf or chewed-leaf cap, in four kinds of brick positioned at the same height: wooden controls (control), red bricks, white bricks and yellow bricks. Y axes presented on a $\log _{10}$ scale. 
Table 2 The occupancy of bee bricks and wooden control bricks in two years of the study (2016 and 2017), divided by different capping types. Chi sq, degrees of freedom (d.f.) and p values (p) are from Friedman's test. Significant results $\left({ }^{*}\right) \mathrm{p}<0.05$. Superscript letters $\left({ }^{\mathrm{a},}\right.$ b) represent significant differences $(\mathrm{p}<0.05)$ between pairs in post hoc tests. \#Not enough data to formally test. No chewed-leaf caps were observed in the height experiment or in the colour experiment in 2016.

\begin{tabular}{|c|c|c|c|c|c|c|c|}
\hline Cap type & Year & $\begin{array}{l}\text { Type of } \\
\text { brick or } \\
\text { position }\end{array}$ & $\begin{array}{l}\text { Mean \% } \\
\text { occupancy per } \\
\text { brick } \pm \text { s.e. } \\
\text { (no. of bricks) }\end{array}$ & $\begin{array}{l}\text { Range } \% \\
\text { occupancy } \\
\text { (min-max) }\end{array}$ & $\begin{array}{l}\text { Chi } \\
\text { sq }\end{array}$ & d.f. & $\mathbf{p}$ \\
\hline \multicolumn{8}{|c|}{ Height experiment } \\
\hline \multirow[t]{4}{*}{ Mud } & 2016 & Control & $4.5 \pm 3.67(15)$ & $0-56$ & 2 & 1 & 0.16 \\
\hline & & Brick & $2.0 \pm 1.71(15)$ & $0-26$ & & & \\
\hline & 2017 & Control & $3.0 \pm 2.17(11)$ & $0-22$ & \# & & \\
\hline & & Brick & $6.7 \pm 6.19(11)$ & $0-68$ & & & \\
\hline \multirow[t]{4}{*}{ Cut-leaf } & 2016 & Control & $1.4 \pm .83(15)$ & $0-11$ & 0.3 & 1 & 0.56 \\
\hline & & Brick & $1.0 \pm 1.08(15)$ & $0-17$ & & & \\
\hline & 2017 & Control & $0.5 \pm 0.51(11)$ & $0-6$ & 1 & 1 & 0.31 \\
\hline & & Brick & $0.0 \pm 0.0(11)$ & $0-0$ & & & \\
\hline \multicolumn{8}{|c|}{ Height comparison (brick only) } \\
\hline \multirow[t]{6}{*}{ Mud } & 2016 & Top & $3.6 \pm 1.92(16)$ & $0-28$ & 4.6 & 2 & 0.10 \\
\hline & & Middle & $2.4 \pm 1.66(16)$ & $0-26$ & & & \\
\hline & & Bottom & $0.0 \pm 0.0(16)$ & $0-0$ & & & \\
\hline & 2017 & Top & $9.9 \pm 4.81(14)$ & $0-58$ & 5.7 & 2 & 0.06 \\
\hline & & Middle & $6.6 \pm 5.17(13)$ & $0-68$ & & & \\
\hline & & Bottom & $1.8 \pm 1.83(12)$ & $0-22$ & & & \\
\hline \multirow[t]{6}{*}{ Cut-leaf } & 2016 & Top & $1.4 \pm .82(16)$ & $0-11$ & 3.2 & 2 & 0.20 \\
\hline & & Middle & $1.1 \pm 1.06(16)$ & $0-17$ & & & \\
\hline & & Bottom & $0.0 \pm 0.0$ & $0-0$ & & & \\
\hline & 2017 & Top & $0.8 \pm 0.79(14)$ & $0-11$ & 1 & 1 & 0.31 \\
\hline & & Middle & $0.0 \pm 0.0$ & $0-0$ & & & \\
\hline & & Bottom & $0.0 \pm 0.0(12)$ & $0-0$ & & & \\
\hline \multicolumn{8}{|c|}{ Colour experiment } \\
\hline \multirow[t]{8}{*}{ Mud } & 2016 & Control & $0.8 \pm 0.75(16)$ & $0-12$ & 1.5 & 3 & 0.68 \\
\hline & & Red & $2.7 \pm 1.88(16)$ & $0-26$ & & & \\
\hline & & White & $4.0 \pm 3.62(16)$ & $0-58$ & & & \\
\hline & & Yellow & $4.4 \pm 3.33(16)$ & $0-53$ & & & \\
\hline & 2017 & Control & $0.0 \pm 0.00(15)^{\mathrm{a}}$ & $0-0$ & 9.1 & 3 & $0.03^{*}$ \\
\hline & & Red & $12.1 \pm 6.45(15)^{b}$ & $0-89$ & & & \\
\hline & & White & $3.2 \pm 2.47(15)^{a b}$ & $0-37$ & & & \\
\hline & & Yellow & $6.1 \pm 3.86(15)^{b}$ & $0-58$ & & & \\
\hline \multirow[t]{8}{*}{ Cut-leaf } & 2016 & Control & $0.0 \pm 0.0(16)$ & $0-0$ & 8.1 & 3 & $0.04^{*}$ \\
\hline & & Red & $2.8 \pm 1.59(16)$ & $0-22$ & & & \\
\hline & & White & $0.4 \pm 0.38(16)$ & $0-6$ & & & \\
\hline & & Yellow & $0.0 \pm 0.0(16)$ & $0-0$ & & & \\
\hline & 2017 & Control & $1.1 \pm 1.13(15)$ & $0-17$ & 3.7 & 3 & 0.30 \\
\hline & & Red & $0.0 \pm 0.0(15)$ & $0-0$ & & & \\
\hline & & White & $0.7 \pm 0.5(15)$ & $0-6$ & & & \\
\hline & & Yellow & $0.0 \pm 0.0(15)$ & $0-0$ & & & \\
\hline \multirow[t]{4}{*}{ Chewed-leaf } & 2017 & Control & $0.0 \pm 0.0(15)^{\mathrm{a}}$ & $0-0$ & 10.6 & 3 & $0.01^{*}$ \\
\hline & & Red & $4.5 \pm 2.22(15)^{b}$ & $0-25$ & & & \\
\hline & & White & $0.7 \pm 0.73(15)^{\mathrm{a}}$ & $0-11$ & & & \\
\hline & & Yellow & $1.9 \pm 1.31(15)^{\mathrm{ab}}$ & $0-17$ & & & \\
\hline
\end{tabular}


This makes it likely that the red bricks provide less of a contrast between cavities and surrounding colour, suggesting potentially the cavities appear more 'camouflaged' to bees. Red bricks may be familiar to bees as nesting sites as red brick walls provide nesting habitat, however high occupancy in bricks was observed in some sites where the local house stock is predominantly rendered.

This study is the first step in determining the impacts of novel bee habitats on solitary bee populations. Previous studies have suggested potential negative impacts of artificial nesting habitats, such as increased use by introduced species rather than native species and increased parasitism rates (MacIvor \& Packer 2015). In the UK few introduced cavity nesting solitary bees have been recorded (Bees Wasps \& Ants Recording Society 2012), but a new cavity nesting wasp was recorded in 2016 (Isodontia mexicana, Bees Wasps \& Ants Recording Society 2020). A new record of a cleptoparasitic bee-fly in the UK was recorded in 2016 (Mills \& Harvey 2016), however it is unknown if the populations of new wasp species or cleptoparasites are increased by the presence of artificial nesting habitats in the UK. Further concerns include the potential for increased pathogens such as mould, bacteria and viruses which have been found in commercial solitary-bee breeding programs (Bosch \& Kemp 2002). Management of bricks might be required to remove old nest material and reduce any potential impacts of disease and predators such as mites. The temperature of cavities is also likely to be strongly affected by being built into houses rather than standalone as tested here; this may be a positive in reducing any potential extremes of temperature or may artificially affect emergence times (Schenk et al. 2018). Further research is required to confirm that the offspring of bees or wasps choosing to use these new nesting habitats are viable and survive through the winter to emerge as adults, and to check the potential impacts on population sizes rather than solely occupancy rates. However, if this novel habitat proves to support cavity-nesting bee populations in urban areas there is the potential to increase solitary-bee populations in housing areas, particularly if implemented in combination with increased floral resources suitable for bees in urban greenspaces (Baldock et al. 2019).

\section{ACKNOWLEDGEMENTS}

This study was funded via University of Exeter funds to $\mathrm{CG}$ and RC. Green\&Blue provided the bee bricks at material cost only. We would like to thank all the people who allowed us to place bee bricks in their gardens for the two years of study. Scott Ford helped with the 2017 fieldwork. Thank you to the editors and two reviewers for their very helpful comments.

\section{REFERENCES}

Baldock, K. C. R., Goddard, M. A., Hicks, D. M., Kunin, W. E., Mitschunas, N., Morse, H., Osgathorpe, L. M., Potts, S. G., Robertson, K. M., Scott, A. V., Staniczenko, P. P. A., Stone, G. N., Vaughan, I. P., \& Memmott, J. (2019). A systems approach reveals urban pollinator hotspots and conservation opportunities. Nature Ecology \& Evolution 3, 363-373. https://doi.org/10.1038/s41559-018-0769-y

Baldock, K. C. R., Goddard, M. A., Hicks, D. M., Kunin, W. E., Mitschunas, N., Osgathorpe, L. M., Potts, S.G., Robertson, K. M., Scott, A. V., Stone, G. N.,Vaughan, I. P., \& Memmott, J. (2015). Where is the UK's pollinator biodiversity? The importance of urban areas for flower-visiting insects. Proceedings of the Royal Society of London B: Biological Sciences, 282. https://doi.org/10.1098/rspb.2014.2849

Bates, D., Maechler, M., Bolker, B., \& Walker, S. (2015). Fitting Linear Mixed-Effects Models Using lme4. Journal of Statistical Software, 67, 1-48. 10.18637/jss.v067.i01.

Bees, Wasps \& Ants Recording Society. (2001). Ancistrocerus antilope (Panzer, 1798). https://www.bwars.com/wasp/vespidae/eumeninae/ ancistrocerus-antilope.

Bees Wasps \& Ants Recording Society. (2012). Bees in Britain. https://www.bwars.com/content/beesbritain

Bees, Wasps \& Ants Recording Society. (2020). Isodontia mexicana Patton, 1880. Retrieved February 10, 2021, from https://www.bwars.com/wasp/sphecidae/isodontiamexicana

Bosch, J., \& Kemp, W.P. (2002). Developing and establishing bee species as crop pollinators: the example of Osmia spp. (Hymenoptera: Megachilidae) and fruit trees. Bulletin of Entomological Research, 92, 3-16. doi:10.1079/BER2001139

Danks, H.V. (1971) Biology of some stem-nesting acualeate Hymenoptera. Transactions of the Royal Entomological Society of London, 122, 323-399. https://doi.org/10.1111/j.13652311.1971.tb00526.x

Dicks, L.V, Showler, D.A., \& Sutherland, W.J. (2010). Bee conservation-evidence for the effects of interventions. Pelagic Publishing, Exeter UK.

Falk, S., \& Lewington, R. (2015). Field Guide to the Bees of Great Britain and Ireland. London: British Wildlife Publishing Ltd.

Friedman, M. (1937) The use of ranks to avoid the assumption of normality implicit in the Analysis of Variance. Journal of the American Statistical Association, 32 , https://doi.org/10.2307/2279372 
Gathmann, A., \& Tscharntke, T. (2002). Foraging ranges of solitary bees. Journal of Animal Ecology, 71, $757-$ $764 . \quad$ https://doi.org/10.1046/j.13652656.2002.00641.x

Hartig, F. (2018). DHARMa: Residual Diagnostics for Hierarchical (Multi-Level / Mixed) Regression Models. $R$ package version 0.2.0. https://cran.r-project.org/package=DHARMa

Hollander, M., Wolfe, D.A. \& Chicken, E. (1999) Nonparametric Statistical Methods. John Wiley \& Sons, New Jersey.

IPBES. (2016). Summary for policymakers of the assessment report of the Intergovernmental Science-Policy Platform on Biodiversity and Ecosystem Services on pollinators, pollination and food production. (Potts, S.G., ImperatrizFonseca, V. L., Ngo, H. T., Biesmeijer, J. C., Breeze, T. D., Dicks, L. V., Garibaldi, L. A., Hill, R., Settele, J., Vanbergen, A. J., Aizen, M. A., Cunningham, S. A., Eardley, C., Freitas, B. M., Gallai, N., Kevan, P. G., KovácsHostyánszki, A., Kwapong, P. K., Li, J., Li, X., Martins, D. J., Nates-Parra, G., Pettis, J. S., Rader, R., Viana, B. F., Eds.). Bonn, Germany: Secretariat of the Intergovernmental SciencePolicy Platform on Biodiversity and Ecosystem Services.

Königslöw, V., Klein, A.-M., Staab, M. \& Pufal, G. 2019 Benchmarking nesting aids for cavitynesting bees and wasps. Biodiversity and Conservation, 28, 3831-3849. https://doi.org/10.1007/s10531-019-01853-1

Lenth, R.V, Singmann, H., Love, J., Buerkner, P., \& Herve, M. (2019). emmeans: Estimated Marginal Means. R Package version 1.4.6. https://CRAN.R-project.org/package=emmeans

Lye, G.C., Park, K.J., Holland, J.M., \& Goulson, D. (2011). Assessing the efficacy of artificial domiciles for bumblebees. Journal of Nature Conservation, $19, \quad 154-160$. https://doi.org/10.1016/j.jnc.2010.11.001
MacIvor, J. S. (2017). Cavity-nest boxes for solitary bees: a century of design and research. Apidologie, 48, 311-327. https://doi.org/10.1007/s13592-0160477-z

MacIvor, J.S., \& Packer, L. (2015). 'Bee Hotels' as tools for native pollinator conservation: a premature verdict? $\quad P L O S \quad O N E, \quad 10$, https://doi.org/10.1371/journal.pone.0122126

Mills, R., \& Harvey, M.C. (2016). Anthrax anthrax (Schrank) (Diptera, Bombyliidae) found in Britain. Dipterists Digest, 23, 225-226.

Osorio-Canadas, S., Arnan, X., Bassols, E., Vicens, N., Bosch, J. (2018) Seasonal dynamics in a cavitynesting bee-wasp community: Shifts in composition, functional diversity and host-parasitoid network structure. $\quad P L O S \quad O N E \quad$ 13, https://doi.org/10.1371/journal.pone.0205854

Peitsch, D., Fietz, A., Hertel, H., de Souza, J., Ventura, D.F., \& Menzel, R. (1992). The spectral input systems of hymenopteran insects and their receptorbased colour vision. Journal of Comparative Physiology A, 170, 23-40. https://doi.org/10.1007/BF00190398

R Core Team. (2016). $R$ : A language and environment for statistical computing. Vienna, Austria: R Foundation for Statistical Computing.

Schenk, M., Mitesser, O., Hovestadt, T., Holzschuh, A. (2018) Overwintering temperature and body condition shift emergence dates of spring-emerging solitary bees. PeerJ, 6, 10.7717/peerj.4721

Threlfall, C.G., Walker, K., Williams, N.S.G., Hahs, A.K., Mata, L., Stork, N., \& Livesley, S.J. (2015). The conservation value of urban green space habitats for Australian native bee communities. Biological Conservation, 187, 240-248. https://doi.org/10.1016/j.biocon.2015.05.003

Wilson, E.S., Murphy, C.E., Rinehart, J.P., Yocum, G. \& Bowsher, J.H. (2020) Microclimate temperatures impact nesting preference in Megachile rotundata (Hymenoptera: Megachilidae). Environmental Entomology 49, 296-303. https://doi.org/10.1093/ee/nvaa012

The Conservation Evidence Journal is an open access online journal devoted to publishing the evidence on the effectiveness of management interventions. The other papers from The Conservation Evidence Journal are available from www.conservationevidencejournal.com. The pdf is free to circulate or add to other websites and is licensed under the Creative Commons Attribution 4.0 International License http://creativecommons.org/licenses/by/4.0/. Under this licence, authors retain ownership of the copyright for their articles. 